\title{
Chronic intracranial hypertension after cerebral venous and sinus thrombosis - frequency and risk factors
}

\author{
Christina Geisbüsch ${ }^{1}$, Christian Herweh², Christoph Gumbinger ${ }^{1}$, Peter A. Ringleb', Markus A. Möhlenbruch ${ }^{2}$ and \\ Simon Nagel ${ }^{1 *}$ (1)
}

\begin{abstract}
Background: Cerebral venous sinus thrombosis (CVST) can infrequently lead to chronical intracranial hypertension $(\mathrm{IH})$ due to the altered venous drainage. The aim of this study was to ascertain the risk of $\mathrm{H}$ after CVST and to stratify underlying risk factors.

Methods: We performed a retrospective cohort analysis of all cases treated for acute CVST at our department between 2013 and 2019. IH was diagnosed at follow-up according to the modified Dandy criteria. CVST-patients with and without $\mathrm{IH}$ were descriptively compared conforming to available clinical and radiological data as well as outcomes.

Results: Our study included 102 patients with acute CVST. In 70 cases complete follow-up data was available (68.6\%). Seven of these patients developed symptomatic intracranial hypertension (10\%; $N=7, n=70)$ within a median follow-up of 6 months. Four of these patients $(57.1 \%(N=4, n=7)$ vs. $3.2 \%(N=2, n=63) ; p<0.001)$ presented recurrent sinus thrombosis in the further course. There were no significant differences between patients with or without IH concerning gender, age, risk factors, occluded vessels and treatment for their CVST. However the presence of visual deterioration at initial admission was higher in patients who developed $\mathrm{IH}$ afterwards (57.1\% $(N=4, n=7)$ vs. $20.6 \%(N=13, n=63) ; p=0.03)$. Patients with chronic IH after CVST showed significantly less likely recanalization of the occluded vessel on follow-up MRI (no recanalization in $28.6 \%(N=2, n=7)$ vs. $4.8 \%(N=3, n=$ 63); $p=0.02$ ). All patients with $\mathbb{H}$ had a good outcome (mRS $0-2$ ) at discharge and follow-up.

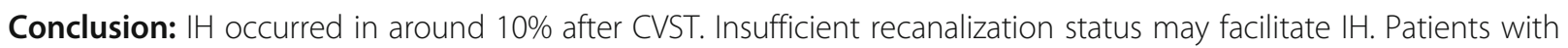
visual disturbances seem to develop more likely $\mathrm{IH}$ afterwards. Patients who present $\mathrm{IH}$ after CVST may develop recurrent cerebral venous thrombosis.
\end{abstract}

Keywords: Intracranial hypertension, Cerebral venous and sinus thrombosis, Visual impairment

\section{Introduction}

Cerebral Venous Sinus Thrombosis (CVST) is a rare cause of stroke with an incidence from 1.3 to 1.6 per 100,000 persons [1] which often occurs in younger adults [2]. In comparison with other stroke subtypes, patients with CVST have generally a more favorable

\footnotetext{
* Correspondence: simon.nagel@med.uni-heidelberg.de

${ }^{1}$ Department of Neurology, Heidelberg University Hospital, Im Neuenheimer Feld 400, 69120 Heidelberg, Germany

Full list of author information is available at the end of the article
}

outcome; up to $80 \%$ are functional independent afterwards [3-5]. Clincal symptoms of CVST can range from headache to severe neurological complications such as loss of consciousness [2]. Moreover, patients may suffer from seizures, aphasia, visual disturbance, motor deficits and other clincial symptoms due to the localization of the thrombosis and its parenchymal lesions [2, 6]. Headache is the most frequent and in most cases the first symptom, whereby acute intracranial hypertension, venous congestion and infarction seem to play a key role

(c) The Author(s). 2021 Open Access This article is licensed under a Creative Commons Attribution 4.0 International License, which permits use, sharing, adaptation, distribution and reproduction in any medium or format, as long as you give appropriate credit to the original author(s) and the source, provide a link to the Creative Commons licence, and indicate if changes were made. The images or other third party material in this article are included in the article's Creative Commons licence, unless indicated otherwise in a credit line to the material. If material is not included in the article's Creative Commons licence and your intended use is not permitted by statutory regulation or exceeds the permitted use, you will need to obtain permission directly from the copyright holder. To view a copy of this licence, visit http://creativecommons.org/licenses/by/4.0/. 
[7]. Headache is also the key symptom of the more chronical course of idiopathic intracranial hypertension. Here, an increased cerebral pressure can be measured by lumbar puncture without evidence of structural reasons as stenosis of a sinus or postthrombotic constrictions [8]. Most prone to this condition are fertile and obese women who can present with visual deteroriations, papilledema and headache [8-10]. Diagnosis of idiopathic intracranial hypertension can be made according to Dandy criteria $[9,11]$. The aetiology remains largely unknown [8], but lumbar punctures to decrease intracranial pressure, therapy with carbonic anhydrase inhibitors and weightloss are recommended to improve symptoms $[9,10]$. CVST can also lead to chronical intracranial hypertension $(\mathrm{IH})$ as a consequence of the altered venous drainage and can affect the overall outcome and quality of life. Previous studies already addressed the relationship between cerebral venous thrombosis and intracranial hypertension [12, 13]. The aim of our study was to estimate the risk of developing IH after CVST and to stratify underlying risk factors for this complication by analysis of a large cohort of CVST-patients with follow-up data from our institution.

\section{Methods}

We performed a retrospective cohort study based on a systematical search in our electronical medical reports for patients who were treated for acute CVST at our Department of Neurology between January 1, 2013 and September 30, 2019. This study was approved by our local ethics committee (S-821/2019).

Patients with CVST were identified by the ICD-10 code (International Classification of Diseases, tenth revision) I67.6. CVST was diagnosed by magnetic resonance imaging (MRI) plus MR venography or computed tomography (CT) plus CT venography [14]. We recorded the following variables: demographic data, symptoms and signs from onset to diagnosis, CT- and MRIfindings, location of the thrombus, risk factors, treatment (acute and post-acute) and outcome at discharge and follow-up. The recanalization status was assessed by an unblinded neuroradiologist as primarily described by Stolz et al. [15]: no recanalization was assumed when the flow signal was still interrupted, a flow signal suggestive of a residual luminal narrowing of at least $50 \%$ was defined as partial recanalization and if the previously affected sinus had an uninterrupted flow signal with a residual luminal narrowing of $<50 \%$ it was evaluated as complete recanalization. Other imaging features were assessed as described in Herweh et al. [14].

Neurological outcome was assessed by an unblinded neurologist according to the modified Rankin Scale (mRS) categorized into independent (mRS 0-2) and dependent (mRS 3-6). All patients were admitted to the stroke unit or the neurointensive care unit and initially treated by either intravenous unfractioned heparin (with target partial thromboplastin time 50-80s) or bodyweight-adjusted low molecular weight heparin (LMWH). After the acute treatment an oral anticoagulation with vitamin $\mathrm{K}$ antagonist (VKA) phenprocoumon or with non-vitamin $\mathrm{K}$ antagonist oral anticoagulants (NOACs) was started. The specific anticoagulant was chosen individually by the treating physician or was based on the patient's inclusion into trials (e.g. RESPECT-CVT [16]). The usual duration of the anticoagulation treatment was at least 6 months after the post-acute phase, but in selected cases and on individual basis the specific anticoagulant was changed during follow-up.

IH was diagnosed at follow-up according to modified Dandy criteria [9, 11], with exception of criterion 4 and in one patient criterion 5 due to relatively contraindicated lumbar puncture (see Table 1). For primary analysis of the recanalization status and clincal outcome at follow-up we selected the first follow-up visit in which a clinical examination and a MRI-scan took place (which was normally scheduled 6 months after CVST). If patients had more than one follow-up visit, we selected the first visit within the follow-up period in which both (a clinical examination and a MRI-scan) were performed for analysis of the recanalization status and clinical outcome. Other information such as recurrent CVST, treatment for IH and ophthalmological outcome was collected at every visit. Characteristics of CVST-patients with and without $\mathrm{IH}$ were then descriptively compared. Intracranial pressure, i.e. IH was measured by lumbar puncture and expressed as $\mathrm{mm} \mathrm{H}^{2} \mathrm{O}$ (water).

\section{Statistical analysis}

We considered demographic, clinical, imaging and treatment variable as possible explanatory variables of developing chronical IH after CVST. Continuous and ordinal variables were calculated as median with range (min$\max$ ). Bivariate analyses were performed for each categorical variable with the Chi-Square-test and MannWhitney-U-Test for continuous variables after testing for normal distribution (with Shapiro-Wilk Test). The level of significance was set at 0.05 (two-sided) and was calculated for all statistical tests. Since no adjustment for multiplicity was performed, the $p$-values need to be interpreted only descriptively and do not allow confirmatory statements. Analysis were conducted using SPSS 25.0 (Armonk, NY: IBM Corp.). The data that support the findings of this study are available from the corresponding author upon reasonable request.

\section{Results}

One hundred and two patients with diagnosed acute CVST according to the aforementioned criteria were 
Table 1 Modified Dandy criteria according to $[9,11]$

\begin{tabular}{ll}
\hline 1 & Symptoms of raised intracranial pressure (headache, nausea, vomiting, transient visual obscurations, or papilledema) \\
3 & No localizing signs with the exception of abducens (sixth) nerve palsy \\
4 & The patient is awake and alert \\
5 & Normal CT/MRI findings without evidence of (acute) thrombosis \\
6 & LP opening pressure of $>25 \mathrm{cmH} 2 \mathrm{O}$ and normal biochemical and cytological composition of CSF \\
\hline
\end{tabular}

enrolled in this study (Table 2). Three patients already died during the acute-phase of the CVST, 8 patients had a clinical follow-up without imaging information and 21 more patients were lost to follow-up. We were able to obtain complete data (including follow-up MRI and clinical examination) of 70 patients with a median follow-up of 6 months (range, 2-42 months). Median age of all patients $(n=70)$ at time of admission was 40.5 years (range $17-77$ years) and around $73 \%$ of all patients were female. Seven CVST-patients developed symptomatic intracranial hypertension (10\%; $N=7, n=70)$ according to the modified Dandy criteria which led to a presentation at the emergency department or at the outpatient clinic.

Three of these seven patients $(42.9 \% ; N=3, n=7)$ presented headache and visual deterioration as symptoms of $\mathrm{IH}$ at a median of 7 months after CVST (1-21 months, Table 3). In two of these three patients this combination of symptoms had simply persisted after their acute CVST. The other patient presented isolated headache at diagnosis of CVST and developed visual problems afterwards. Three patients $(42.9 \% ; N=3, n=7)$ only reported visual disturbances without headache at follow-up: One of these 3 patients never had any kind of headache, the second patient developed visual worsening several weeks after CVST and had isolated headache when CVST was diagnosed and the third patient presented headache and visual disturbances as CVST-symptoms. The seventh patient complained about remaining headaches at followup whereas CVST had caused various symptoms such as focal seizures, dysarthria and paresis without any headache or visual symptoms before.

Median cerebrospinal fluid opening pressure of these seven patients was $455 \mathrm{mmH}^{2} \mathrm{O}\left(270-550 \mathrm{mmH}^{2} \mathrm{O}\right)$. Lumbar punctures of patients with CVST who did not develop signs of $\mathrm{IH}$ in the further course were only performed in two cases and intracranial pressure was not measured. Four of the patients who developed chronic IH $(57.1 \%$ vs. $3.2 \% ; p<0.001)$ presented recurrent sinus thrombosis in the further course (Table 3). But there were no significant differences between patients with or without IH concerning gender, age, risk factors for developing a CVST and the specific occluded vessels. In addition there were no significant alterations in treatment for the CVST and changes of the anticoagulation regime due to MRI findings at follow-up between these groups. However, the presence of visual deterioration at initial admission for CVST was higher in patients who developed IH afterwards $(57.1 \%(N=4, n=7)$ vs. $20.6 \%$ $(N=13, n=63) ; p=0.03)$. All patients with $\mathrm{IH}$ had a functional independent outcome (mRS 0-2) at initial hospital discharge and follow-up, whereas $81 \%$ of all patients without $\mathrm{IH}$ were functional independent at initial discharge and $92 \%$ were functionally independent at follow-up. Patients with IH showed significantly more often no recanalization of the occluded vessels on follow-up MRI $(28.6 \%(N=2, n=7)$ vs. $4.8 \%(N=3, n=$ $63) ; p=0.02$ ). Four of the five patients with no recanalization (two patients with $\mathrm{IH}$ and two patients without IH) still had an extensive thrombosis of the left sinus transversus and sigmoideus intruding the Vena jugularis at follow-up. Only one patient presented at follow up with continued occlusion of a bridging vein.

Treatment of $\mathrm{IH}$ in this cohort was heterogenic and individualized for each patient (Table 3). Five patients were treated with acetazolamide. For two of these, this therapy was sufficient and improved their symptoms, whereas three cases required additional treatment or intervention. In two patients who were initially treated with acetazolamide ventriculoperitonital shunting was necessary due to refractory headaches, optic atrophy with potential visual loss. One of these five patients showed intolerance to acetazolamide which is why therapy with torasemid was started instead and the anticoagulation therapy with NOAC (dabigatran) was resumed. In one case therapeutic lumbar punctures were temporarily repeated and the anticoagulation therapy was changed from vitamin $\mathrm{K}$ antagonist to dabigatran. In another patient endovascular therapy was attempted promptly after recurrent CVST (partial recanalization after 1st CVST), but unfortunately neither mechanical thrombectomy nor stenting of an underlying stenosis was technically possible. This patient then developed cerebral AV-fistula in the further course and was successfully treated with recurrent embolisations. In five cases the symptoms related to $\mathrm{IH}$ were reduced, one patient remained with a severe papillary atrophy without any further visual worsening and one patient who is still under follow-up suffers from continuing headaches with improved papilledema and visual symptoms in partial remission. 
Table 2 Characteristics of all CVST-patients, all CVST-patients with Follow-up Data, CVST- patients without IH and with IH. Age is expressed as median (min-max) with *Mann-Whitney-U-Test, categorical data expressed as n (\%) with Chi-Square-Test

\begin{tabular}{|c|c|c|c|c|c|}
\hline & $\begin{array}{l}\text { All CVST } \\
(n=102)\end{array}$ & $\begin{array}{l}\text { All CVST with Follow-up Data } \\
(n=70)\end{array}$ & $\begin{array}{l}\text { CVST without } \\
\text { IH } \\
(n=63)\end{array}$ & $\begin{array}{l}\text { CVST with IH } \\
(n=7)\end{array}$ & $p$-value \\
\hline Gender female & $75(73.5 \%)$ & $51(72.9 \%)$ & $46(73 \%)$ & $5(71.4 \%)$ & 0.93 \\
\hline Age, years & $40.5(17-77)$ & $40.5(17-77)$ & $41(17-77)$ & $40(19-67)$ & $0.83^{*}$ \\
\hline \multicolumn{6}{|l|}{ Symptoms and signs } \\
\hline Headache & $84(82.4 \%)$ & $58(82.9 \%)$ & $52(82.5 \%)$ & $6(85.7 \%)$ & 0.83 \\
\hline Isolated headache & $23(22.5 \%)$ & $19(27.1 \%)$ & $17(27 \%)$ & $2(28.6 \%)$ & 0.93 \\
\hline Visual disturbance & $20(19.6 \%)$ & $17(24.3 \%)$ & $13(20.6 \%)$ & $4(57.1 \%)$ & 0.03 \\
\hline Paresis & $25(24.5 \%)$ & $16(22.9 \%)$ & $15(23.8 \%)$ & $1(14.3 \%)$ & 0.57 \\
\hline Aphasia & $16(15.7 \%)$ & $7(10 \%)$ & $7(11.1 \%)$ & - & 0.35 \\
\hline Focal seizures & $14(13.7 \%)$ & $12(17.1 \%)$ & $11(17.5 \%)$ & $1(14.3 \%)$ & 0.80 \\
\hline Seizure with generalization & $23(22.6 \%)$ & $12(17.1 \%)$ & $12(19 \%)$ & - & 0.20 \\
\hline Any seizure & $37(36.3 \%)$ & $26(37.1 \%)$ & $25(39.7 \%)$ & $1(14.3 \%)$ & 0.19 \\
\hline Mental status disorder & $14(13.7 \%)$ & $8(11.4 \%)$ & $7(11.1 \%)$ & $1(14.3 \%)$ & 0.80 \\
\hline Disturbed consciousness & $13(12.7 \%)$ & $4(5.7 \%)$ & $4(6.3 \%)$ & - & 0.49 \\
\hline \multicolumn{6}{|l|}{ CT/MR findings } \\
\hline Infarct one hemisphere & $19(18.6 \%)$ & $11(15.7 \%)$ & $11(17.5 \%)$ & - & 0.23 \\
\hline Infarct both hemispheres & $5(4.9 \%)$ & $2(2.9 \%)$ & $2(3.2 \%)$ & - & 0.63 \\
\hline Hemorrhage one hemisphere & $35(34.3 \%)$ & $21(30 \%)$ & $18(28.6 \%)$ & $3(42.9 \%)$ & 0.43 \\
\hline Hemorrhage both hemispheres & $9(8.8 \%)$ & $4(5.7 \%)$ & $4(6.3 \%)$ & - & 0.49 \\
\hline \multicolumn{6}{|l|}{ Occluded sinus/vein } \\
\hline Superior sagittal sinus & $43(42.5 \%)$ & $30(42.9 \%)$ & $28(44.4 \%)$ & $2(28.6 \%)$ & 0.42 \\
\hline One/Both lateral sinus & $\begin{array}{l}75(73.5 \%) / 7 \\
(6.9 \%)\end{array}$ & $53(75.7 \%) / 5(7.1 \%)$ & $\begin{array}{l}47(74.6 \%) / 4 \\
(6.3 \%)\end{array}$ & $\begin{array}{l}6(85.7 \%) / 1 \\
(14.3 \%)\end{array}$ & $\begin{array}{l}0.52 / \\
0.44\end{array}$ \\
\hline Straight sinus & $14(13.7 \%)$ & $9(12.9 \%)$ & $8(12.7 \%)$ & $1(14.3 \%)$ & 0.91 \\
\hline Inner cerebral veins & $8(7.8 \%)$ & $3(4.3 \%)$ & $3(4.8 \%)$ & - & 0.56 \\
\hline Cortical veins & $23(22.6 \%)$ & $17(24.3 \%)$ & $16(25.3 \%)$ & $1(14.3 \%)$ & 0.52 \\
\hline Jugular veins & $36(35.3 \%)$ & $28(40 \%)$ & $24(38.1 \%)$ & $4(57.2 \%)$ & 0.33 \\
\hline $\begin{array}{l}\text { Multiple thrombosis in more than one dural } \\
\text { sinus/vein }\end{array}$ & $62(60.8 \%)$ & $48(68.6 \%)$ & $43(68.3 \%)$ & $5(71.4 \%)$ & 0.86 \\
\hline $\begin{array}{l}\text { Thrombus extending from lateral sinus into } \\
\text { jugular vein }\end{array}$ & $34(33.3 \%)$ & $27(38.6 \%)$ & $23(36.5 \%)$ & $4(57.2 \%)$ & 0.29 \\
\hline \multicolumn{6}{|l|}{ Risk factors } \\
\hline Thrombophilia & $28(27.5 \%)$ & $20(28.6 \%)$ & $19(30.2 \%)$ & $1(14.3 \%)$ & 0.38 \\
\hline Malignancy & $11(10.8 \%)$ & $5(7.1 \%)$ & $4(6.3 \%)$ & $1(14.3 \%)$ & 0.44 \\
\hline Pregnancy & $1(1 \%)$ & $1(1.4 \%)$ & $1(1.6 \%)$ & - & 0.74 \\
\hline Puerperium & $1(1 \%)$ & - & - & - & - \\
\hline Oral contraceptives & $25(24.5 \%)$ & $21(30 \%)$ & $19(30.2 \%)$ & $2(28.6 \%)$ & 0.93 \\
\hline Vaginal ring & $6(5.9 \%)$ & $6(8.6 \%)$ & $6(9.5 \%)$ & - & 0.39 \\
\hline Steroid therapy & $13(12.7 \%)$ & 9 (12.9\%) & $9(14.3 \%)$ & - & 0.28 \\
\hline Cytotoxic therapy & $8(7.8 \%)$ & $4(5.7 \%)$ & $4(6.3 \%)$ & - & 0.49 \\
\hline Smoking & $9(8.8 \%)$ & $7(10 \%)$ & $6(9.5 \%)$ & $1(14.3 \%)$ & 0.69 \\
\hline Head injury & $4(3.9 \%)$ & $3(4.3 \%)$ & $3(4.8 \%)$ & - & 0.56 \\
\hline \multicolumn{6}{|l|}{ Treatment - acute phase } \\
\hline LMWH & $74(72.5 \%)$ & $55(78.6 \%)$ & 49 (77.8\%) & $6(85.7 \%)$ & 0.63 \\
\hline
\end{tabular}


Table 2 Characteristics of all CVST-patients, all CVST-patients with Follow-up Data, CVST- patients without IH and with IH. Age is expressed as median (min-max) with *Mann-Whitney-U-Test, categorical data expressed as n (\%) with Chi-Square-Test (Continued)

\begin{tabular}{|c|c|c|c|c|c|}
\hline & $\begin{array}{l}\text { All CVST } \\
(n=102)\end{array}$ & $\begin{array}{l}\text { All CVST with Follow-up Data } \\
(n=70)\end{array}$ & $\begin{array}{l}\text { CVST without } \\
\text { IH } \\
(n=63)\end{array}$ & $\begin{array}{l}\text { CVST with IH } \\
(n=7)\end{array}$ & $p$-value \\
\hline Heparine i.v. & $24(23.5 \%)$ & $13(18.6 \%)$ & $13(20.6 \%)$ & - & 0.18 \\
\hline Hemicraniectomy & $7(6.9 \%)$ & $4(5.7 \%)$ & $4(6.3 \%)$ & - & 0.49 \\
\hline Mechanical thrombectomy & $11(10.8 \%)$ & $4(5.7 \%)$ & $3(4.8 \%)$ & $1(14.3 \%)$ & 0.30 \\
\hline \multicolumn{6}{|l|}{ Treatment - post-acute phase } \\
\hline OAK & $39(38.2 \%)$ & $29(41.4 \%)$ & $26(41.3 \%)$ & $3(42.9 \%)$ & 0.94 \\
\hline NOAK & $44(43.1 \%)$ & $35(50 \%)$ & $31(49.2 \%)$ & $4(57.1 \%)$ & 0.69 \\
\hline Rivaroxaban & $25(24.5 \%)$ & $21(30 \%)$ & 19 (30.2\%) & $2(28.6 \%)$ & 0.93 \\
\hline Dabigatran & $18(17.6 \%)$ & $13(18.6 \%)$ & $12(19 \%)$ & $1(14.3 \%)$ & 0.76 \\
\hline \multicolumn{6}{|l|}{ Outcome at discharge } \\
\hline mRS $0-2$ at discharge & 75 (73.5\%) & $58(82.9 \%)$ & $51(81 \%)$ & $7(100 \%)$ & 0.20 \\
\hline \multicolumn{6}{|l|}{ Outcome at follow-up } \\
\hline mRS 0-2 at follow-up & & 65 (92.9\%) & $58(92.1 \%)$ & $7(100 \%)$ & 0.44 \\
\hline Complete recanalization & & $18(25.7 \%)$ & $16(25.4 \%)$ & $2(28.6 \%)$ & 0.86 \\
\hline Partial recanalization & & $47(67.1 \%)$ & $44(69.8 \%)$ & $3(42.9 \%)$ & 0.15 \\
\hline No recanalization & & $5(7.1 \%)$ & $3(4.8 \%)$ & $2(28.6 \%)$ & 0.02 \\
\hline Recurrent sinus thrombosis & & $6(8.6 \%)$ & $2(3.2 \%)$ & $4(57.1 \%)$ & $<0.001$ \\
\hline
\end{tabular}

\section{Discussion}

In our study $10 \%$ of CVST-patients developed chronical $\mathrm{IH}$ according to the modified Dandy criteria in the further course and received specific treatment for this complication despite having a functional independent outcome at discharge and follow-up. We identified as underlying risk factors no recanalization on follow-up MRI and the presence of visual symptoms at the initial diagnosis of CVST. Patients who developed IH afterwards also seemed to be prone to recurrent sinus thrombosis. IH is a clinical complication after CVST that can influence the overall outcome and can have a relevant impact on the quality of life [17], even though affected patients often present a functional independent neurological outcome as measured with the mRS.

Acute CVST can mimick idiopathic IH. In a study of Biousse et al. 59 patients out of a cohort of 160 consecutive CVST-patients (37\%) only presented symptoms of $\mathrm{IH}$ such as headache with or without visual deterioration as signs for their acute CVST; lumbar puncture with measurement of the opening pressure was performed in 32 of these 59 CVST-patients and a raised intracranial pressure was confirmed in 25 cases (78\%) [18]. In a subgroup analysis of the International Study on Cerebral Vein and Dural Sinus Thrombosis (ISCVT) raised intracranial pressure was found in $83.3 \%$ of 127 patients [19]. Hence, $\mathrm{IH}$ in patients with acute CVST is very common and a major pathophysiological mechanism to explain disease related symptoms.
Yet, up to date, it remains uncertain how many patients develop symptomatic, chronic $\mathrm{IH}$ in the further course after CVST and which patients may be under increased risk to do so. In our study, $10 \%$ of patients presented with isolated symptoms of $\mathrm{IH}$ at a median time of 7 months (range 1-21 months) after their CVST. It is likely that in the majority of the remaining patients the initially raised intracranial pressure slowly returned to normal with recanalization of the occluded vessel and/or establishment of collateral venous flow. Interestingly, there were no significant differences between CVSTpatients with or without IH concerning gender, age, risk factors for developing a CVST in the first place, specific occluded vessels or anticoagulation treatment for the CVST. Most of our patients had a complete or partial recanalization at follow-up and only five of all CVSTpatients $(7.1 \%)$ had no recanalization. These recanalization rates correspond with other studies $[20,21]$. However, and supporting the above mentioned hypothesis, patients with failed recanalization despite anticoagulation had more often $\mathrm{IH}$ as a complication than others. Therefore a lack of recanalization seem to be a risk factor for IH after first CVST. While some studies could not find any association between functional neurological outcome and recanalization status [14, 15, 20-23], a systematic review and meta-analyasis of 19 studies could show that a lack of venous recanalization was associated with a worse clinical outcome [24]. Another retrospective observational multicenter cohort study with 508 
Table 3 Characteristics of chronic IH for each patient

\begin{tabular}{|c|c|c|c|c|c|c|c|}
\hline & Patient 1 & Patient 2 & Patient 3 & Patient 4 & Patient 5 & Patient 6 & Patient 7 \\
\hline $\begin{array}{l}\text { Time of } \mathbb{H} \\
\text { diagnosis }\end{array}$ & 2 months after CVST & $\begin{array}{l}7 \text { months } \\
\text { after CVST }\end{array}$ & $\begin{array}{l}8 \text { months } \\
\text { after CVST }\end{array}$ & $\begin{array}{l}11 \text { months } \\
\text { after CVST }\end{array}$ & $\begin{array}{l}1 \text { month } \\
\text { after CVST }\end{array}$ & $\begin{array}{l}5 \text { months after } \\
\text { CVST }\end{array}$ & $\begin{array}{l}21 \text { months } \\
\text { after CVST }\end{array}$ \\
\hline Symptoms of $\mathrm{IH}$ & $\begin{array}{l}\text { headache double vision, } \\
\text { papilledema }\end{array}$ & $\begin{array}{l}\text { headache, } \\
\text { visual } \\
\text { disturbances }\end{array}$ & $\begin{array}{l}\text { headache, } \\
\text { visual } \\
\text { disturbances }\end{array}$ & $\begin{array}{l}\text { visual } \\
\text { disturbances, } \\
\text { papilledema }\end{array}$ & $\begin{array}{l}\text { visual } \\
\text { disturbances }\end{array}$ & $\begin{array}{l}\text { visual } \\
\text { disturbances }\end{array}$ & $\begin{array}{l}\text { Headache, } \\
\text { delirium }\end{array}$ \\
\hline $\begin{array}{l}\text { Symptoms of } \\
\text { previous CVST }\end{array}$ & $\begin{array}{l}\text { headache, visual } \\
\text { disturbances }\end{array}$ & $\begin{array}{l}\text { isolated } \\
\text { headache }\end{array}$ & $\begin{array}{l}\text { headache, } \\
\text { visual } \\
\text { disturbances }\end{array}$ & $\begin{array}{l}\text { isolated } \\
\text { headache }\end{array}$ & $\begin{array}{l}\text { headache, } \\
\text { visual } \\
\text { disturbances }\end{array}$ & $\begin{array}{l}\text { visual } \\
\text { disturbances }\end{array}$ & $\begin{array}{l}\text { headache, } \\
\text { paresis, focal } \\
\text { seizures }\end{array}$ \\
\hline $\begin{array}{l}\text { Recanalization } \\
\text { status }\end{array}$ & partial & $\begin{array}{l}\text { no } \\
\text { recanalization }\end{array}$ & complete & partial & complete & no recanalization & partial \\
\hline CVST recurrence & yes ( 9 months after CVST) & $\begin{array}{l}\text { yes ( } 1 \text { month } \\
\text { and } 12 \\
\text { months after } \\
\text { CVST) }\end{array}$ & no & $\begin{array}{l}\text { yes ( } 12 \text { months } \\
\text { after CVST) }\end{array}$ & no & no & $\begin{array}{l}\text { yes (in the } \\
\text { further course) } \\
\text { plus } \\
\text { Dural fistulas }\end{array}$ \\
\hline $\begin{array}{l}\text { CSF pressure - at } \\
\text { the time of } \\
\text { diagnosis }\end{array}$ & $500 \mathrm{mmH}^{2} \mathrm{O}$ & $330 \mathrm{mmH}^{2} \mathrm{O}$ & $270 \mathrm{mmH}^{2} \mathrm{O}$ & $410 \mathrm{mmH}^{2} \mathrm{O}$ & $550 \mathrm{mmH}^{2} \mathrm{O}$ & $500 \mathrm{mmH}^{2} \mathrm{O}$ & not performed \\
\hline Treatment of $\mathrm{IH}$ & $\begin{array}{l}\text { initially acetazolamide and } \\
\text { frequently lumbar punctures; } \\
\text { due to remaining symptoms } \\
\text { after insufficient attempt of } \\
\text { mechanical recanalization, } \\
\text { shunt-operation }\end{array}$ & acetazolamide & acetazolamide & $\begin{array}{l}\text { intolerant to } \\
\text { acetazolamide, } \\
\text { short-time } \\
\text { therapy with } \\
\text { torasemide }\end{array}$ & $\begin{array}{l}\text { repeated } \\
\text { lumbar } \\
\text { punctures }\end{array}$ & $\begin{array}{l}\text { initially } \\
\text { acetazolamide, } \\
\text { but due to } \\
\text { increasing CSF } \\
\text { pressure and } \\
\text { papilledema } \\
\text { shunt-operation }\end{array}$ & $\begin{array}{l}\text { insufficient } \\
\text { attempt of } \\
\text { mechanical } \\
\text { recanalization, } \\
\text { embolization } \\
\text { of fistulas }\end{array}$ \\
\hline Outcome (mRS) & $\begin{array}{l}\text { symptom-free } \\
\text { (mRS 0) }\end{array}$ & $\begin{array}{l}\text { improved } \\
\text { symptoms } \\
\text { but remaining } \\
\text { headaches } \\
\text { (mRS 1) }\end{array}$ & $\begin{array}{l}\text { symptom-free } \\
\text { (mRS 0) }\end{array}$ & $\begin{array}{l}\text { symptom-free } \\
\text { (mRS 0) }\end{array}$ & $\begin{array}{l}\text { symptom- } \\
\text { free } \\
\text { (mRS 0) }\end{array}$ & $\begin{array}{l}\text { improved } \\
\text { symptoms } \\
\text { (mRS 1) }\end{array}$ & $\begin{array}{l}\text { improved } \\
\text { symptoms } \\
\text { (mRS 2) }\end{array}$ \\
\hline $\begin{array}{l}\text { Ophthalmological } \\
\text { Control }\end{array}$ & improved papilledema & $\begin{array}{l}\text { improved } \\
\text { papilledema }\end{array}$ & $\begin{array}{l}\text { no } \\
\text { abnormalities }\end{array}$ & not performed & $\begin{array}{l}\text { not } \\
\text { performed }\end{array}$ & $\begin{array}{l}\text { improved } \\
\text { papilledema on } \\
\text { the right, severe } \\
\text { left papillary } \\
\text { atrophy }\end{array}$ & not performed \\
\hline
\end{tabular}

patients also revealed an association between recanalization status and functional outcome [25]. Some authors suggest that residual headache, i.e. persistent $\mathrm{IH}$, is more common in patients with no recanalization $[22,26]$. One study showed that complete recanalization rates were lower in patients with multiple thrombosis in more than one dural sinus [20]. Whereas some authors could draw the conclusion that thrombosis of the superior sagittal sinus was a positive predictor of recanalization [14], in another study the sigmoid sinus recanalized more often [21]. Among the five patients in our study that did not show any recanalization at follow up, $80 \%$ had an extensive thrombosis from lateral sinus into jugular vein. A recent study could also show that there were no differences between patients that were treated with dagibatran or warfarin concerning recanalization rates [23].

Our findings also lead to the assumption that patients who present visual disturbances as a symptom of their CVST seem to develop symptomatic IH more likely afterwards. Visual symptoms are described as a common complication of CVST-associated $\mathrm{IH}[27,28]$. According to Ding et al. there is a clear association of the magnitude of intracranial pressure and visual loss; a pressure $\geq$ $330 \mathrm{mmH}^{2} \mathrm{O}$ may be a cut-off value that predicts visual damage in CVST-patients [27]. Although these values were derived from a cohort of acute CVST-patients, the high cerebrospinal fluid (CSF) opening pressure (median $455 \mathrm{mmH}^{2} \mathrm{O}, 270-550 \mathrm{mmH}^{2} \mathrm{O}$ ) that was measured in our CVST-patients with chronic IH at follow up indicates a clear association with the increased frequency of visual symptoms in this subset of patients. Hence, as a clinically relevant consequence, patients with CVST and visual symptoms at presentation or during follow-up, should be closely monitored and medical treatment or interventions for IH should be considered early in these cases to avoid further visual deteroriation.

The present data cannot help to further elucidate the differences between patients who suffer from idiopathic $\mathrm{IH}$ versus those who develop $\mathrm{IH}$ as a secondary event. Features of patients with $\mathrm{IH}$ originating from idiopathic cause or from CVST, including CSF opening pressure, are very similar and the two entities may only be 
differentiated by imaging of the intracranial venous system $[12,29,30]$. However, isolated raised intracranial pressure from CVST differs in management from $\mathrm{IIH}$ and should be classified neither as "idiopathic IH" nor as "pseudotumor cerebri" [18]. The treatment of IH in our cohort was heterogenic (Table 3) and also included a switch in the anticoagulation regime for CVST in two patients.

This study has some limitations. First, a possible source of bias is the retrospective design of this study. Second, due to the prevalence of CVST the cohort was relatively small $(n=102)$ and there was a lack of complete follow-up data for some CVST-patients (lost-to-follow-up, $n=32$ ). The reason for the lack of follow-up data remains unclear. One possible explanation could be that patients applied for post-acute follow-up appointments with physicians closer to their home. Another interpretation of the missing data could be that patients with very severe CVST or no symptoms at all after CVST might miss follow-up visits more likely. For 8 patients we obtained clinical data without imaging information, five of these patients showed an independent outcome at follow-up, two patients were dependent and one patient died due to other reasons. Furthermore we were not able to receive information for 21 patients (neither neurological nor neuroradiological). Twelve of these 21 patients had an independet outcome at hospital discharge whereas 9 patients were functional dependent at that point of time. These numbers seem to underline the above mentioned hypothesis. Third, lumbar punctures were not systematically performed on all CVST-patients at follow-up, but only when IH was clinically suspected by the treating physician. In one $\mathrm{IH}$-patient lumbar puncture was not performed due to secondary dural fistulas (Table 3). Third, the fact that our $\mathrm{IH}$-patients presented with very high CSF opening pressure (median $455 \mathrm{mmH}^{2} \mathrm{O}$ ) suggests that we might have missed less severe cases of $\mathrm{IH}$. Therefore the prevalence of $\mathrm{IH}$ might be higher than reported.

\section{Conclusions}

$\mathrm{IH}$ is not a rare complication in the further course after CVST with possibly serious consequences to patients' visual function. Therefore a follow-up visit including thorough anamnesis, clinical examination and a MRI scan with venography should be performed for each CVST-patient. Since visual symptoms and failed recanalization seem to indicate an increased risk of IH after CVST, an ophthalmologic consultation and diagnostic lumbar punctures should be considered in these cases to identify patients who might require specific IH treatment next to their anticoagulation regime.

\section{Abbreviations}

CVST: Cerebral venous sinus thrombosis; $\mid \mathrm{H}$ : Intracranial hypertension; mRS: Modified Rankin Scale; LMWH: Low molecular weight heparin; VKA: Vitamin K antagonist; NOACs: Non-vitamin K antagonist oral anticoagulants

\section{Acknowledgements}

The authors wish to thank Stefan Moschny for his assistance in collecting data for this study.

Dr. Christina Geisbüsch was supported by a scholarship of the Faculty of Medicine of the University of Heidelberg.

\section{Authors' contributions}

CGe wrote the paper, acquired and analyzed the data. $\mathrm{CH}, \mathrm{CGu}, \mathrm{PR}, \mathrm{MM}$ made critical revision and edits to the manuscript. SN designed the study, analyzed the data and made critical revisions and edits to the manuscript. The author(s) read and approved the final manuscript.

\section{Funding}

N.A.

\section{Availability of data and materials}

The data that support the findings of this study are available from the corresponding author upon reasonable request.

\section{Declarations}

\section{Ethics approval and consent to participate}

This study was approved by our local ethics committee (S-821/2019), medical faculty of University of Heidelberg. Patient informed consent waived due to the retrospective nature of the study.

\section{Consent for publication}

N.A.

\section{Competing interests}

Christina Geisbüsch-none.

Christian Herweh-UNRELATED: Consultancy: Brainomix, Oxford, UK,

Christoph Gumbinger-UNRELATED: Speaker of the commission teleneurology service of the German Stroke Society.

Peter A. Ringleb-UNRELATED: Consultancy: Boehringer, Lecture fees from Bayer, Boehringer Ingelheim, BMS, Daichii Sankyo, Pfizer.

Markus A. Möhlenbruch—UNRELATED: Board Membership: Codman; Consultancy: Medtronic, MicroVention, Stryker; Payment for Lectures Including Service on Speakers Bureaus: Medtronic, MicroVention, Stryker. *Money paid to the institution.

Simon Nagel__UNRELATED: Consultancy: Brainomix, Boehringer Ingelheim; Payment for Lectures Including Service on Speakers Bureaus: Pfizer, Medtronic, Bayer AG.

\section{Author details}

'Department of Neurology, Heidelberg University Hospital, Im Neuenheimer Feld 400, 69120 Heidelberg, Germany. ${ }^{2}$ Department of Neuroradiology, Heidelberg University Hospital, Heidelberg, Germany.

Received: 16 February 2021 Accepted: 4 May 2021

Published online: 17 May 2021

\section{References}

1. Coutinho, J. M., Zuurbier, S. M., Aramideh, M., \& Stam, J. (2012). The incidence of cerebral venous thrombosis: a cross-sectional study. Stroke, 43(12), 3375-3377 [Research Support, Non-U.S. Gov't].

2. Ferro, J. M., Canhao, P., Stam, J., Bousser, M. G., \& Barinagarrementeria, F. (2004). Prognosis of cerebral vein and dural sinus thrombosis: results of the International Study on Cerebral Vein and Dural Sinus Thrombosis (ISCVT). Stroke, 35(3), 664-670 [Multicenter Study Research Support, Non-U.S. Gov't].

3. Bousser, M. G., \& Ferro, J. M. (2007). Cerebral venous thrombosis: an update. Lancet Neurology, 6(2), 162-170 [Review].

4. Dentali, F., Gianni, M., Crowther, M. A., \& Ageno, W. (2006). Natural history of cerebral vein thrombosis: a systematic review. Blood, 108(4), 1129-1134 [Review Systematic Review]. 
5. Stam, J. (2005). Thrombosis of the cerebral veins and sinuses. The New England Journal of Medicine, 352(17), 1791-1798 [Review].

6. Geisbusch, C., Lichy, C., Richter, D., Herweh, C., Hacke, W., \& Nagel, S. (2014). Clinical course of cerebral sinus venous thrombosis. Data from a monocentric cohort study over 15 years. Nervenarzt., 85(2), 211-220. https:// doi.org/10.1007/s00115-013-4000-8.

7. Alberti, A., Venti, M., \& Biagini, S. (2008). Headache and cerebral vein and sinus thrombosis. Frontiers of Neurology and Neuroscience, 23, 89-95 [Review].

8. Hoffmann, J., Mollan, S. P., Paemeleire, K., Lampl, C., Jensen, R. H., \& Sinclair, A. J. (2018). European headache federation guideline on idiopathic intracranial hypertension. The Journal of Headache and Pain, 19(1), 93 [Practice Guideline].

9. Wall, M. (2017). Update on idiopathic intracranial hypertension. Neurologic Clinics, 35(1), 45-57 [Review].

10. Smith, S. V., \& Friedman, D. I. (2017). The idiopathic intracranial hypertension treatment trial: a review of the outcomes. Headache, 57(8), 1303-1310 [Review].

11. Friedman, D. I., \& Jacobson, D. M. (2002). Diagnostic criteria for idiopathic intracranial hypertension. Neurology, 59(10), 1492-1495 [Review].

12. Turay, S., Kabakus, N., Hanci, F., Tunclar, A., \& Hizal, M. (2019). Cause or consequence: the relationship between cerebral venous thrombosis and idiopathic intracranial hypertension. Neurologist, 24(5), 155-160. https://doi. org/10.1097/NRL.0000000000000242.

13. Onder, H., \& Kisbet, T. (2020). Neuroimaging findings in patients with idiopathic intracranial hypertension and cerebral venous thrombosis, and their association with clinical features. Neurological Research, 42(2), 141-147. https://doi.org/10.1080/01616412.2019.1710408.

14. Herweh, C., Griebe, M., Geisbusch, C., Szabo, K., Neumaier-Probst, E., Hennerici, M. G., et al. (2016). Frequency and temporal profile of recanalization after cerebral vein and sinus thrombosis. European Journal of Neurology, 23(4), 681-687. https://doi.org/10.1111/ene.12901.

15. Stolz, E., Trittmacher, S., Rahimi, A., Gerriets, T., Rottger, C., Siekmann, R., et al. (2004). Influence of recanalization on outcome in dural sinus thrombosis: a prospective study. Stroke, 35(2), 544-547 [Clinical Trial].

16. Ferro, J. M., Coutinho, J. M., Dentali, F., Kobayashi, A., Alasheev, A., Canhão, P. , et al. (2019). Safety and efficacy of dabigatran etexilate vs dose-adjusted warfarin in patients with cerebral venous thrombosis: a randomized clinical trial. JAMA Neurology, 76(12), 1457-1465. https://doi.org/10.1001/jama neurol.2019.2764.

17. Saposnik, G., Barinagarrementeria, F., Brown Jr., R. D., Bushnell, C. D. Cucchiara, B., Cushman, M., et al. (2011). Diagnosis and management of cerebral venous thrombosis: a statement for healthcare professionals from the American Heart Association/American Stroke Association. Stroke, 42(4), 1158-1192 [Practice Guideline Review].

18. Biousse, V., Ameri, A., \& Bousser, M. G. (1999). Isolated intracranial hypertension as the only sign of cerebral venous thrombosis. Neurology, 53(7), 1537-1542. https://doi.org/10.1212/WNL.53.7.1537.

19. Canhao, P., Abreu, L. F., Ferro, J. M., Stam, J., Bousser, M. G.,

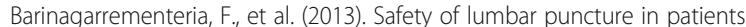
with cerebral venous thrombosis. European Journal of Neurology, 20(7), 1075-1080. https://doi.org/10.1111/ene.12136.

20. Gazioglu, S., Eyuboglu, I., Yildirim, A., Aydin, C. O., \& Alioglu, Z. (2017). Cerebral venous sinus thrombosis: clinical features, long-term outcome and recanalization. Journal of Clinical Neuroscience, 45, 248-251. https://doi.org/1 0.1016/j.jocn.2017.07.028

21. Singh, V. K., Jain, N., Kalita, J., Misra, U. K., \& Kumar, S. (2020). Significance of recanalization of sinuses and resolution of parenchymal lesion in cerebral venous sinus thrombosis. Journal of Clinical Neuroscience, 77, 175-180. https://doi.org/10.1016/.jocn.2020.04.112.

22. Putaala, J., Hiltunen, S., Salonen, O., Kaste, M., \& Tatlisumak, T. (2010). Recanalization and its correlation to outcome after cerebral venous thrombosis. Journal of the Neurological Sciences, 292(1-2), 11-15. https://doi. org/10.1016/j.jns.2010.02.017

23. Ferro, J. M., Bendszus, M., Jansen, O., Coutinho, J. M., Dentali, F., Kobayashi, A., et al. (2021). Recanalization after cerebral venous thrombosis. A randomized controlled trial of the safety and efficacy of dabigatran etexilate versus dose-adjusted warfarin in patients with cerebral venous and dural sinus thrombosis. International Journal of Stroke, 4, 17474930211006303.

24. Aguiar de Sousa, D., Lucas Neto, L., Canhao, P., \& Ferro, J. M. (2018). Recanalization in cerebral venous thrombosis. Stroke, 49(8), 1828-1835. https://doi.org/10.1161/STROKEAHA.118.022129.
25. Rezoagli, E., Martinelli, I., Poli, D., Scoditti, U., Passamonti, S. M., Bucciarelli, P., ... Dentali, F. (2018). The effect of recanalization on long-term neurological outcome after cerebral venous thrombosis. Journal of Thrombosis and Haemostasis, 16(4), 718-724. https://doi.org/10.1111/jth.13954.

26. Strupp, M., Covi, M., Seelos, K., Dichgans, M., \& Brandt, T. (2002). Cerebral venous thrombosis: correlation between recanalization and clinical outcome--a long-term follow-up of 40 patients. Journal of Neurology, 249(8), 1123-1124.

27. Ding, J., Zhou, D., Geng, T., Pan, L., Ya, J., Wang, Z., et al. (2018). To predict visual deterioration according to the degree of intracranial hypertension in patients with cerebral venous sinus thrombosis. European Neurology, 80(12), 28-33 [Research Support, Non-U.S. Gov't].

28. Zhao, T., Wang, G., Dai, J., Liu, Y., Wang, Y., \& Li, S. (2018). Cases of visual impairment caused by cerebral venous sinus occlusion-induced intracranial hypertension in the absence of headache. BMC Neurology, 18(1), 159. https://doi.org/10.1186/s12883-018-1156-7.

29. Sylaja, P. N., Ahsan Moosa, N. V., Radhakrishnan, K., Sankara Sarma, P., \& Pradeep, K. S. (2003). Differential diagnosis of patients with intracranial sinus venous thrombosis related isolated intracranial hypertension from those with idiopathic intracranial hypertension. Journal of the Neurological Sciences, 215(1-2), 9-12. https://doi.org/10.1016/S0022-510X(03)00182-5.

30. Leker, R. R., \& Steiner, I. (1999). Features of dural sinus thrombosis simulating pseudotumor cerebri. European Journal of Neurology, 6(5), 601-604. https:// doi.org/10.1046/j.1468-1331.1999.650601.x.

\section{Publisher's Note}

Springer Nature remains neutral with regard to jurisdictional claims in published maps and institutional affiliations.

Ready to submit your research? Choose BMC and benefit from:

- fast, convenient online submission

- thorough peer review by experienced researchers in your field

- rapid publication on acceptance

- support for research data, including large and complex data types

- gold Open Access which fosters wider collaboration and increased citations

- maximum visibility for your research: over $100 \mathrm{M}$ website views per year

At $\mathrm{BMC}$, research is always in progress.

Learn more biomedcentral.com/submission 